\title{
Evaluation of NEXRAD Radar Precipitation Products for Natural Resource Applications
}

\author{
Stuart P. Hardegree, ${ }^{1}$ Steven S. Van Vactor, ${ }^{2}$ David H. Levinson, ${ }^{3}$ and Adam H. Winstral ${ }^{4}$ \\ Authors are ${ }^{1}$ Plant Physiologist, USDA Agricultural Research Service, Northwest Watershed Research Center, 800 Park Blvd, Suite 105, Boise, ID 83712, \\ USA; ${ }^{2}$ Hydrologist, USDA-ARS-NWRC, Boise, ID 83712, USA; ${ }^{3}$ Physical Scientist, Climate Monitoring Branch, NOAA/NESDIS National Climate \\ Data Center, Ashville, NC 28801, USA; and ${ }^{4}$ Hydrologist, USDA-ARS-NWRC, Boise, ID 83712, USA.
}

\begin{abstract}
Timing and amount of precipitation are principal drivers of most rangeland processes, but the availability of rainfall-gauge data over extensive rangelands, particularly in the western United States, is limited. The National Weather Service (NWS), Department of Defense, and Federal Aviation Administration operate a network of Doppler radar stations that produce hourly rainfall estimates, at approximately $16-\mathrm{km}^{2}$ resolution, with nominal coverage of $96 \%$ of the conterminous United States. Internal utilization of these data by the three agencies is primarily for the detection and modeling of extreme weather events. The usefulness of these data for external hydrologic and natural resource applications is limited by a lack of tools for decoding and georeferencing digital precipitation data products. We modified NWS source code to produce decoding and georeferencing tools and used them to evaluate radar precipitation data for the Boise (CBX) radar relative to gauges in the Snake River Plain of southwestern Idaho for the period January 1998 to May 2004. The relationship between radar and gauge precipitation estimates changed after a revision of radar-processing protocols in 2002 and 2003. Cumulative radar precipitation estimates made prior to November 2002 underestimated gauge readings by $50 \%-60 \%$. Subsequent radar data overestimated cumulative gauge precipitation by $20 \%-40 \%$. The radar, however, detected precipitation during significantly fewer hours than were detected by the gauge network both before and after programming changes. Additional modification of NWS precipitationprocessing procedures might improve accessibility and utility of these data for rangeland management and natural resource modeling applications. Currently available data can still be very useful for estimating high-intensity events that greatly affect processes such as soil erosion and flooding.
\end{abstract}

\section{Resumen}

La temporada y cantidad de precipitación son las causas primarias que afectan a la mayoría de los procesos del pastizal, sin embargo, la disponibilidad de información sobre la precipitación registrada en pastizales nativos, particularmente en el Oeste de los Estados Unidos, es limitada. El Servicio Nacional del Clima (NWS), el Departamento de la Defensa, y la Administración Federal de Aviación fungen como una red de las estaciones del radar Doppler que producen estimaciones de la precipitación cada hora con una resolución aproximada de $16 \mathrm{~km}^{2}$ y cobertura nominal del $96 \%$ de los Estados Unidos. La utilización interna de estos datos por las tres agencias es principalmente para la detección y modelaje de acontecimientos climáticamente extremos. La utilidad de estos datos para usos hidrológicos y aplicaciones en recursos naturales es limitada por la carencia de herramientas para descifrar y georeferenciar productos digitales derivados de la precipitación registrada. Se realizaron modificaciones del código de fuente de NWS para producir herramientas que descifren y georeferencien. Estas herramientas se utilizaron para evaluar los datos de la precipitación registrada con el radar de Boise (CBX) en la planicie del Rio de la Serpiente al suroeste de Idaho desde enero de 1998 hasta mayo de 2004. La relación entre el radar y las estimaciones de la precipitación registrada cambió después de una revisión de los procesos del radar en los protocolos de 2002 y 2003. Estimaciones acumulativas realizadas antes de Noviembre 2002, subestimaron la precipitación registrada por el radar en 50\%-60\%. Los datos subsecuentes del radar sobrestimaron la precipitación acumulativa por $20 \%-40 \%$. Sin embargo, el radar sensiblemente detectó la precipitación durante pocas horas de que ésta fuera detectada por la red antes y después de los cambios programados. La modificación adicional de los procedimientos de los procesos de la precipitación de NWS puede mejorar la accesibilidad y la utilidad de esta información para el adecuado manejo de los pastizales y el uso de aplicaciones en el modelaje de los recursos naturales. Los datos disponibles actualmente pueden todavía ser muy útiles para estimar los acontecimientos de alta intensidad que afectan grandemente procesos tales como inundaciones y la erosión.

Key Words: Doppler radar, meteorology, precipitation, watershed management, WSR-88D

\section{INTRODUCTION}

Research was funded in part by the Bureau of Land Management, Intermountain Greenstripping and Restoration Project.

Correspondence: Stuart P. Hardegree, USDA-ARS, 800 Park Blvd, Suite 105, Boise, ID 83712, USA. Email: stuart.hardegree@ars.usda.gov

Manuscript received 14 April 2007; manuscript accepted 20 December 2007.
The National Weather Service (NWS), Department of Defense, and Federal Aviation Administration operate approximately 160 WSR-88D Doppler radar stations as part of a Next Generation Radar (NEXRAD) program that began implementation in 1991. These radar stations provide spatial rainfall estimates, at approximately $16-\mathrm{km}^{2}$ resolution, with nominal coverage of $96 \%$ of the conterminous United States (Crum et 
al. 1998). Effective coverage, especially in the western United States, might be much less due to beam blockage in areas of complex topography (Kingsmill and Huggins 1999; Westrick et al. 1999; Maddox et al. 2002).

The original intent of this network was to support operational objectives of the Departments of Defense, Transportation, and Commerce (Crum and Alberty 1993; Whiton et al. 1998a, 1998b; Anagnostou and Krajewski 1999a). Collection and interpretation of these data have been optimized for detection and mitigation of severe weather events, such as tornadoes and thunderstorms, that might result in flooding, destruction of property, and loss of life (Baeck and Smith 1998; Crum et al. 1998; Winchell et al. 1998; Witt et al. 1998a, 1998b; Anagnostou and Krajewski 1999a; Fulton 1999; Brown et al. 2000; Warner et al. 2000). The primary hydrologic application has been river and flood-forecast modeling by 13 NWS River Forecast Centers (RFC). Because each RFC is responsible for a large river drainage area, optimization of data processing and quality control are geared toward a relatively large spatial domain $\left(>100000 \mathrm{~km}^{2}\right.$; Anagnostou and Krajewski 1998; Seo et al. 1999).

Ideas for practical application of WSR-88D precipitation data to agricultural and natural resource management are easily derived, but have been slow to be implemented (Brandes et al. 1991; Nelson et al. 1996; Hunter et al. 2003; Jordan et al. 2003; Di Luzio and Arnold 2004; Hossain et al. 2004; Neary et al. 2004; Zhang et al. 2004). Previous studies have evaluated the utility of WSR-88D precipitation datasets as input to nonNWS hydrologic models but focused on parameter sensitivity and variability rather than the spatial accuracy of the data (Winchell et al. 1998; Koren et al. 1999; Carpenter et al. 2001; Hunter et al. 2003; Jordan et al. 2003; Di Luzio and Arnold 2004; Hossain et al. 2004; Sharif et al. 2004; Zhang et al. 2004). Utilization of WSR-88D precipitation data by the NWSRFC system occurs in real time within the context of a custom programming/database/analysis system that is inaccessible to most external users (Anagnostou and Krajewski 1998). Digital, distributed precipitation radar products can be obtained from the NWS, but hourly precipitation files are stored in a binarycoded format for which there are no commercially available software or analysis tools. Georeferencing tools for comparing WSR-88D precipitation products with ground-based measurements also are relatively difficult to obtain and must be adapted for use outside of the NWS-RFC application domain. Development of tools to facilitate accessibility of radar precipitation products can result in product utilization in a larger number of applications than are currently supported (Hunter 1996; Crum et al. 1998; Steiner et al. 1999; Young et al. 2000; Snow and Scott 2003).

The purposes of this paper are 1) to describe the WSR-88D precipitation processing system; 2) to describe data format issues and data-decoding tools for assessing and manipulating WSR-88D Stage I, Level III spatial precipitation data; 3) to describe georeferencing tools for locating gauge sites relative to NEXRAD precipitation cells; 4) to compare NEXRAD and gauge estimates of cumulative precipitation for the Boise, Idaho (CBX) radar location; and 5) to propose modifications to existing data acquisition and management protocols to make these data more useful for rangeland and natural resource management applications.

\section{THE WSR-88D PRECIPITATION- PROCESSING SYSTEM}

The existing protocol for WSR-88D precipitation estimation consists of three processing stages (Anagnostou and Krajewski 1998; Fulton et al. 1998). Stage I occurs at the individual radar site and produces spatial rainfall estimates for a single radar domain. Stages II and III involve, respectively, multisensor bias adjustment and creation of a multiradar mosaic of precipitation estimates for areas with overlapping radar coverage.

Stage I, Level-I radar data are composed of raw analog output from the radar scanning process. Stage I, Level II processing produces reflectivity estimates for every radial volume scan $(5,6$, or $10 \mathrm{~min})$, in a polar grid with each of 82800 bins representing $1^{\circ}$ of arc and $1 \mathrm{~km}$ distance out to a radius of $230 \mathrm{~km}$. The radar measures reflectivity in each bin at multiple elevation angles between $0.5^{\circ}$ and $19.5^{\circ}$ (Young et al. 1999). A computer program resident at the radar site selects an appropriate elevation angle for every bin based on a map of potential beam blockage for a given site location (Fulton et al. 1998). The resident computer program also conducts a number of error checking procedures and estimates precipitation rate $(R)$ for each bin as a function of reflectivity $(Z)$.

The default relationship between $Z$ and $R$ is based on a power function, $R=a Z^{b}$, where $a=0.017$ and $b=0.714$ (Young et al. 1999). Z-R coefficients have been shown to vary as a function of many factors, and it is not possible to derive a single equation that is accurate at every point in a given radar domain, and for every storm type and storm intensity (Austin 1987; Hunter 1996; Glitto and Choy 1997; Anagnostou and Krajewski 1999a; Ciach and Krajewski 1999; Ulbrich and Lee 1999). NWS radar operators, however, are permitted to select from several different $Z-R$ relationships for an individual radar location and time period. Radar processing also involves selection of a precipitation detection function (pdf), which establishes a threshold reflectivity, below which radar rainfall estimates are set to zero (Anagnostou and Krajewski 1998; Fulton 1999; Kingsmill and Huggins 1999). Selection of appropriate $Z-R$ and pdf coefficients can significantly affect the accuracy of Level III precipitation data but must be implemented at the Level II processing stage.

The WSR-88D precipitation processing system aggregates and remaps Level II radar data into Level III data, which are composed of hourly precipitation estimates that are spatially distributed on the Hydrologic Rainfall Analysis Project (HRAP) grid (Reed and Maidment 1999). The HRAP grid is a standardized grid, superimposed on the United States, with approximately $16-\mathrm{km}^{2}$ spatial resolution. Remapping of polar precipitation estimates on the HRAP grid, as Level III data, facilitates comparison and utilization of data for locations with overlapping radar coverage.

Three programming changes were made to the Boise (CBX) precipitation processing system during the time period studied: 5 November 2002; 15 May 2003; and 22 October 2003. Some of these software changes were initiated to correct errors in precipitation detection, and precipitation detection thresholds (Fulton et al. 2003; Istok et al. 2003). Subsequent analyses were conducted to separate these time periods to determine whether changes in radar gauge precipitation relationships were correlated to changes in the precipitation processing software 
on the radar. Data between November 1998 and May 2004 were evaluated in six 7-mo blocks (November-May) to optimize comparisons of precipitation detection subsequent to software changes.

\section{DATA FORMAT AND DECODING PROCEDURES}

Stage I, Level III, WSR-88D precipitation data are output as a series of Digital Precipitation Array (DPA) files, each containing the aggregate precipitation estimate for the previous hour in a binary-coded format (Fulton et al. 1998). Upon decoding, the DPA file consists of a header that contains radar site information, followed by precipitation estimates for 17161 HRAP grid cells surrounding the radar location.

Individual hourly DPA files can be obtained from the NOAA National Climate Data Center (NCDC; http://hurricane.ncdc. noaa.gov/pls/plhas/has.dsselect). The US Department of Agriculture National Wildlife Research Center developed a computer program in the Perl programming language (Decode.pl), which we modified from the original source code obtained from the NWS Hydrologic Research Laboratory in Silver Springs, Maryland. Decode.pl converts binary-coded DPA files into ASCII-formatted files that contain a precipitation estimate, in $\mathrm{mm}$, for every row and column within the 17161-cell local HRAP grid domain. Current files are labeled DPA and have a different structure than older files that were labeled HDP (Hourly Digital Precipitation). A transition period also occurred when files with the new HDP format were labeled as DPA files. Decode.pl will decode older, newer, and transition files by calling specific subroutines, depending upon the nature of the file that it is tasked to decode. If no precipitation is detected during a given hour, the DPA file header contains a flag indicating that all of the precipitation values are zero.

\section{RADAR AND GAUGE GEOREFERENCING}

The HRAP grid is a polar stereographic projection in which the United States is divided into discrete cells (Reed and Maidment 1999). These cells are designated by numbers indicating row $(1-881)$ and column $(1-1121)$, relative to a reference point west of Baja California (cell 1,1), and cover the 48 conterminous states (Fulton 1998). Each cell in the HRAP grid is approximately $4 \mathrm{~km} \times 4 \mathrm{~km}$ but the exact size varies with distance from the reference point. DPA file data are georeferenced relative to a local HRAP grid, which is defined as a 131 $\times 131$-cell subdomain of the national HRAP grid. As with the national-HRAP grid, row 1, column 1 of the local grid is located at the southern- and westernmost corner of the array. Row numbers increase moving north of row 1 and column numbers increase moving east of column 1 . We developed a computer program in C programming language (Gauges_lh. exe) using code from existing NWS algorithms to georeference radar and gauge data relative to both the local and national HRAP grids. This program takes a specific radar location and list of gauge locations (latitude and longitude in decimal degrees) and outputs both the national and local HRAP row, column, and cell ID for the radar location and each gauge. The

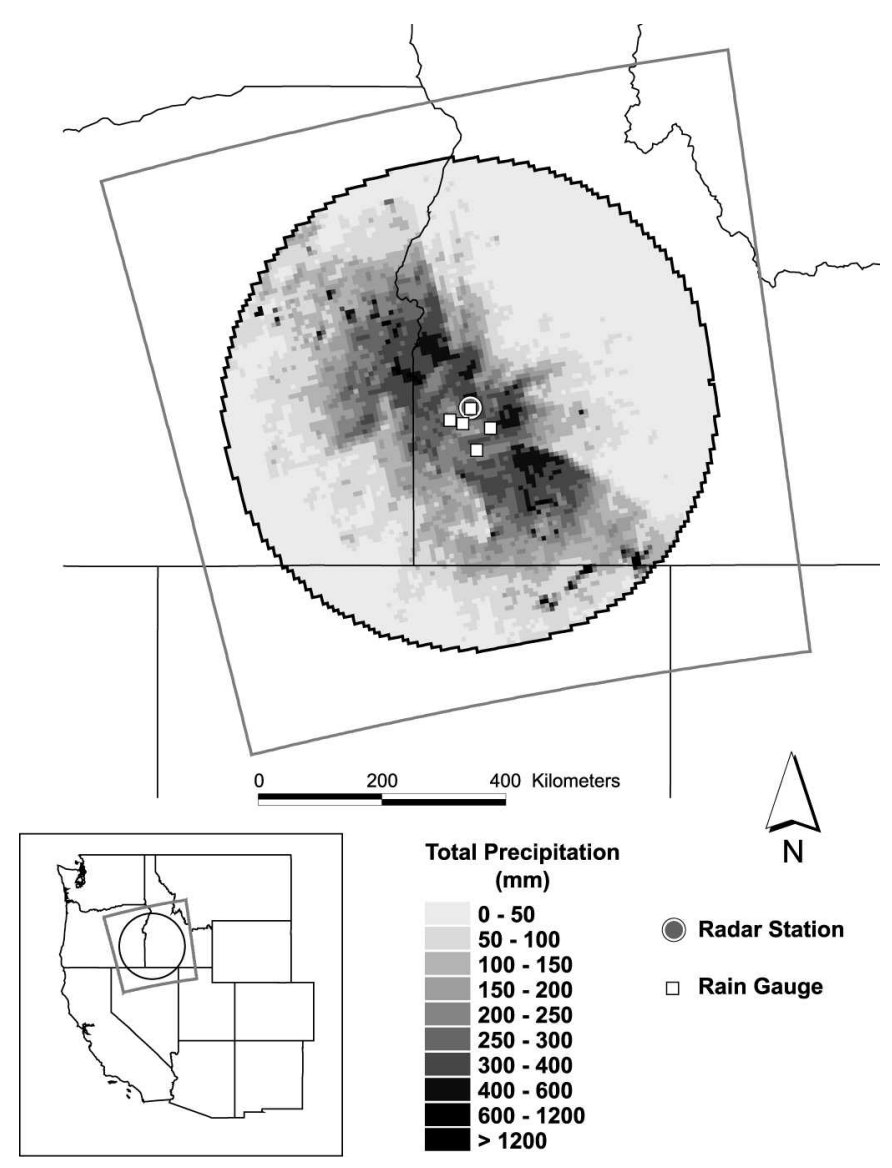

Figure 1. Three-year cumulative rainfall in the Boise (CBX) radar domain. Polygon represents row and column limits for local HRAP grid. Circle represents $230-\mathrm{km}$ radius of coverage for the Level III data product.

cell ID is a unique number corresponding to each row and column within the HRAP grid. Row 1, column 1 of the local HRAP grid has a cell ID of 1, progressing to row 131, column 131 , which has a cell ID of 17161 . The local HRAP location for a given radar is always within row 66 and column 66, which has a cell ID of 8581. All programs used for decoding and georeferencing DPA file data, for both Windows and UNIX operating systems, are available from the authors.

\section{COMPARISON OF RADAR AND GAUGE DATA}

Four precipitation gauges in the Snake River Birds of Prey National Conservation Area were georeferenced relative to the Boise (CBX) radar, and the national and local HRAP grid. Precipitation was measured with shielded universal recording gauges with a $30.48-\mathrm{cm}$ orifice at a height of $3.05 \mathrm{~m}$ aboveground. The shield was an Alter-type with the baffles constrained at an angle of $30^{\circ}$ from vertical as described by Hanson et al. (1999). These gauges were all within $40 \mathrm{~km}$ of the CBX radar location (953 $\mathrm{m}$ above sea level [asl]) in relatively flat terrain and did not have any significant beamblockage issues. A polygon connecting these gauge locations represents an area of approximately $435 \mathrm{~km}^{2}$ with a total elevational range of $880-980 \mathrm{~m}$ asl. The gauges used in this study were well within the effective sensing domain of the CBX 


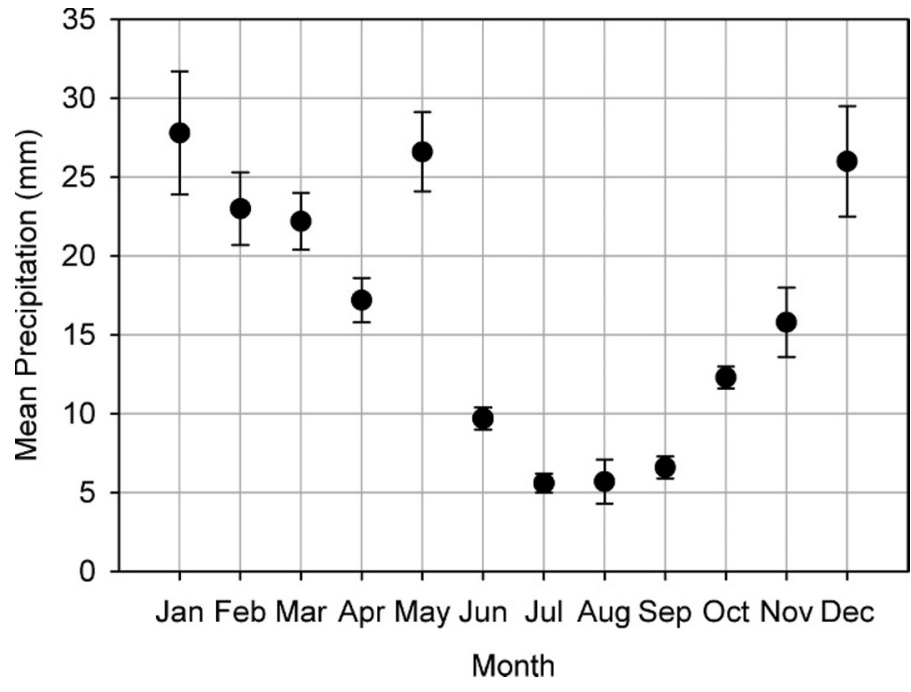

Figure 2. Mean monthly precipitation ( \pm 1 SE) among gauge sites during the study period (January 1998-May 2004).

radar. Figure 1 shows the cumulative precipitation estimate for the CBX radar domain for a 3-yr test period. The general shape of the detected precipitation domain is very similar to that presented by Maddox et al. (2002) for the Boise radar location. Over the course of the study, approximately $80 \%$ of the annual precipitation during a given year, as measured by the gauge network, fell during the November-May time period in which data were evaluated for this study (Fig. 2).

Level III data files were obtained from NCDC for January 1998 through May 2004. These data were decoded and aggregated into a temporal and spatial database from which hourly precipitation estimates were derived for gauged cell locations. DPA files contain $1 \mathrm{hr}$ of cumulative precipitation estimates, but these $1 \mathrm{hr}$ accumulation periods do not necessarily coincide with the exact hour as measured by the rain gauge network. The Boise radar location (CBX) estimates cumulative hourly precipitation for the hour prior to each scan, which can be at intervals of 5, 6, or $10 \mathrm{~min}$, depending upon atmospheric conditions within the radar domain. We selected the DPA file for the hour most representative of the gauge measurement interval. Radar data were not used for hours in which a DPA file was unavailable for the period \pm 6 min from the top of the hour.

The radar record for the test period was incomplete. In addition to missing time periods, some radar files contained a flag noting insufficient data, bad data, or disk errors during a given hour. Valid DPA files were available for only $93 \%$ of the hours in any given year ( $\pm 2 \%$ standard error of the mean). Mean annual gauge precipitation during the periods when NEXRAD data were unavailable constituted $6 \%( \pm 1 \%)$ of the total gauge precipitation measured during the study period.

Of the hours in which radar data were available, and for which there were no error flags, the total number of hours in which precipitation was detected by the radar was significantly less than the number of hours of precipitation detection by the gauge network (Fig. 3A). The relative number of hours in which the radar detected rainfall increased after October 2002, and again after October 2003, coinciding with radar reprogramming

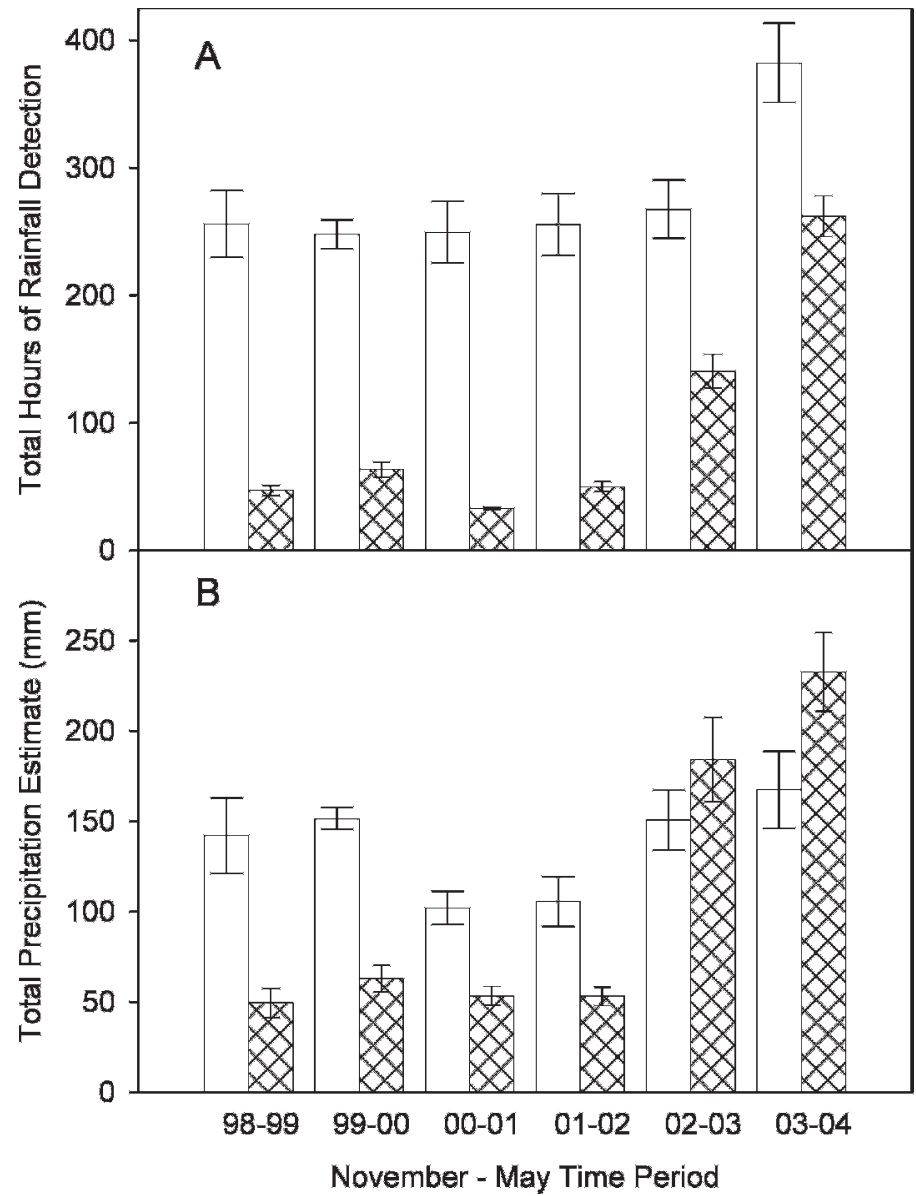

Figure 3. Total hours of detected rainfall (A) and total estimated precipitation (B) for rain gauges (solid bars) and radar (hatched bars) during the six November-May test periods. Error bars represent \pm 1 standard error of the mean.

events (Fig. 3A). Simultaneous precipitation detection by the gauge network and the radar was more likely to occur during higher-intensity events. Hourly rainfall rates for gauges, across all locations and sites, averaged only $0.34( \pm 0.05) \mathrm{mm} \cdot \mathrm{h}^{-1}$ during periods when only the gauges were detecting rainfall events, but averaged $0.98( \pm 0.08) \mathrm{mm} \cdot \mathrm{h}^{-1}$ during periods when both the radar and gauges were detecting rainfall events. The ratio of radar to gauge precipitation amount is frequently used as an estimate of radar gauge bias (Glitto and Choy 1997; Anagnostou and Krajewski 1998; Anagnostou et al. 1998; Seo 1998; Ciach and Krajewski 1999; Seo et al. 1999; Steiner et al. 1999; Ulbrich and Lee 1999; Ciach et al. 2000; Seo et al. 2000). This ratio was less than $54 \%$ during the first four test periods, but rose to between $123 \%$ and $141 \%$ subsequent to programming changes in 2002 and 2003 (Fig. 3B).

Mean monthly precipitation estimates for both radar and gauges are plotted in Figure 4 for the period prior to May 2002, and during the subsequent two November-May test intervals. Correlation of radar and gauge estimates during the first two periods (Figs. 4A and 4B) was very low, but improved during the final time period (Fig. 4C). Radar precipitation estimates were significantly lower than gauge estimates prior to May 2002 (Figs. 3B and 4A), indistinguishable from gauge estimates between November 2002 and May 2003 (Figs. 3B 


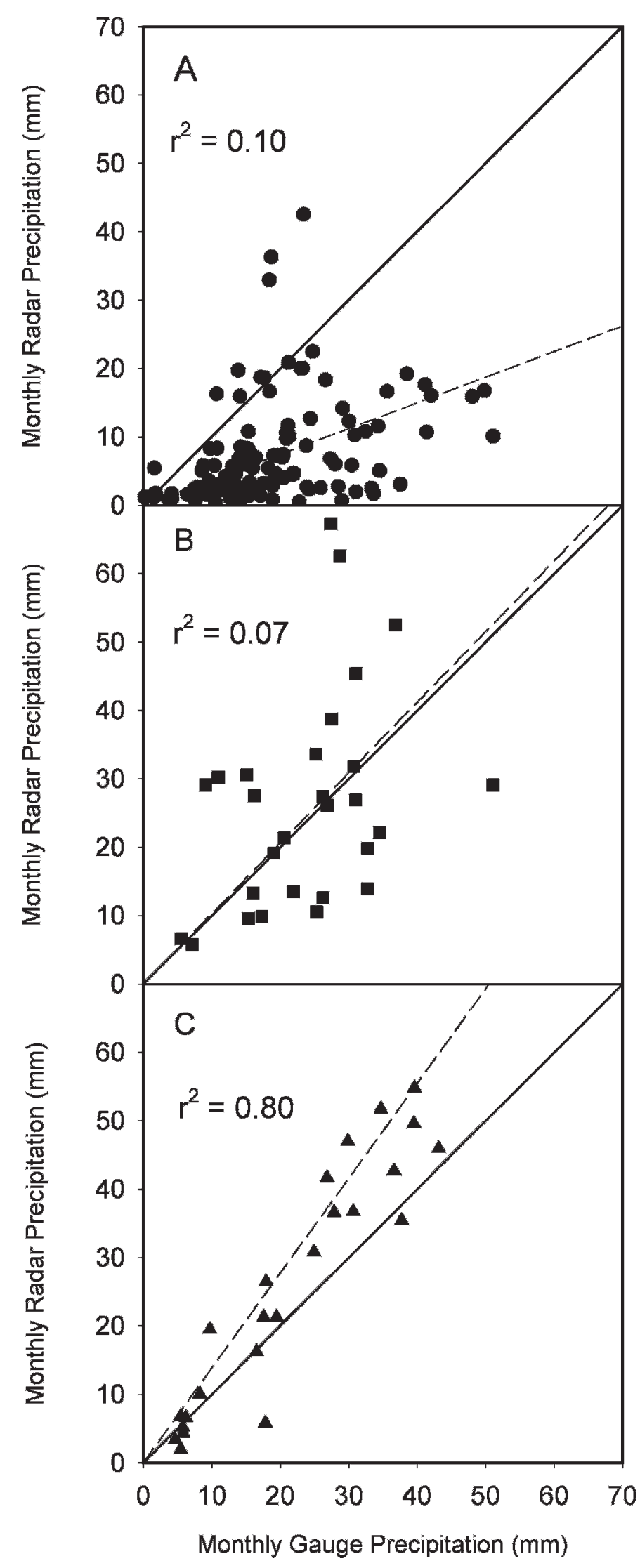

Figure 4. Monthly radar precipitation estimates vs. monthly gauge precipitation estimates for the four test periods before May $2002(\mathbf{A})$, the 2002-2003 test period (B), and the 2003-2004 test period (C). The dashed lines represent the linear regression relationships for the data.

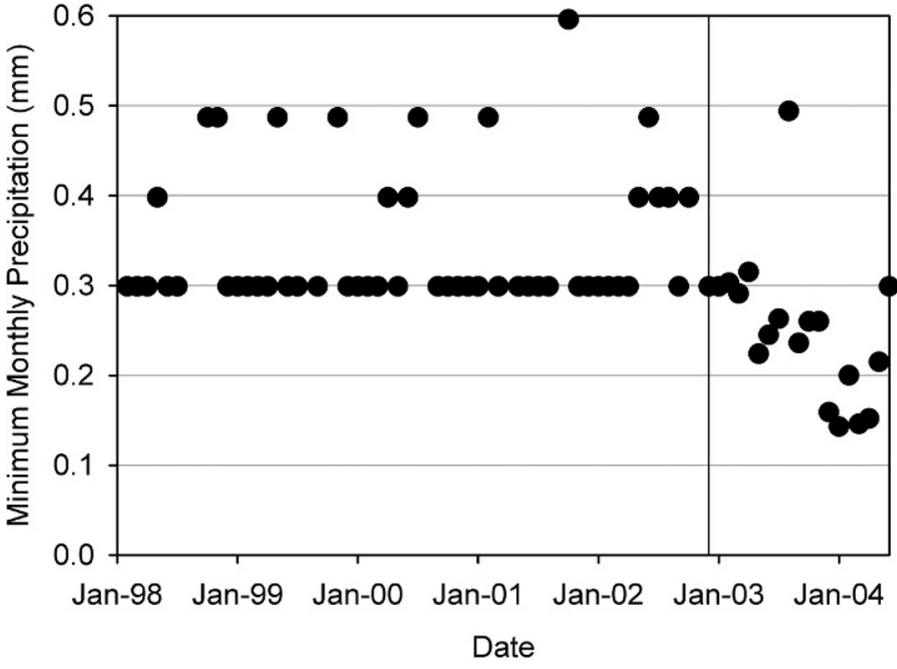

Figure 5. Minimum hourly radar precipitation estimates $(\mathrm{mm})$ for each month within all gauged cells for the entire measurement period. Vertical line represents November 2002, after which all software changes were made at the radar.

and $4 \mathrm{~B})$, and significantly greater than gauge estimates after November 2003 (Figs. 3B and 4C).

The precipitation detection function determines the minimum reflectivity at which the radar acknowledges a precipitation event. This function should define the minimum value returned by the radar for precipitation estimation during a given hour. Figure 5 shows the minimum hourly radar precipitation detected by the radar among all gauged cells as a function of time. This figure shows that the radar detected some lower-intensity storm events subsequent to radar programming changes in 2002 and 2003, resulting from utilization of a lower precipitation detection function.

\section{DISCUSSION}

Radar data products are subject to three types of error that affect the accuracy of precipitation estimates: mean field systematic bias, range dependent systematic error, and random error (Hunter 1996; Seed et al. 1996; Smith et al. 1996; Anagnostou and Krajewski 1998; Anagnostou et al. 1998; Anagnostou and Krajewski 1999a; Ciach and Krajewski 1999; Steiner et al. 1999; Young et al. 1999; Young et al. 2000). Gauge data can be used to improve the accuracy of WSR-88D radar precipitation estimates in two ways: in development of more accurate model coefficients, such as $Z-R$ relationships and pdf values, for Level II data processing; and in postestimate bias correction of Level III DPA data (Glitto and Choy 1997; Anagnostou and Krajewski 1998; Anagnostou et al. 1998; Seo 1998; Ciach and Krajewski 1999; Seo et al. 1999; Steiner et al. 1999; Ulbrich and Lee 1999; Ciach et al. 2000; Seo et al. 2000). Error detection and optimization of radar precipitation products is almost always conducted by comparing radarprecipitation estimates with ground-truth gauge data (Smith et al. 1996; Anagnostou and Krajewski 1998, 1999a; Anagnostou et al. 1998, 1999; Seo 1998; Fulton 1999; Seo et al. 1999, 2000; Steiner et al. 1999; Morin et al. 2003; Neary et al. 2004). 
For our data, range dependent systematic errors were probably not a factor because the gauge locations were relatively close together, were not subject to beam blockage and were well within the maximum range of precipitation detection. Random errors would be expected to increase the variability in radar and gauge rainfall estimates but would not be expected to affect mean values over time. We attribute the majority of the discrepancy between gauge and radar estimates in this study to mean field systematic bias. Specifically, the majority of gauge events appear to have occurred below the detection threshold set by the pdf function. We infer this from two types of evidence: mean hours with positive gauge measurements during the November to May test period far exceeded hours in which the radar detected precipitation (Fig. 3B); and mean rainfall intensity measured by the gauge-network when the radar was not detecting rainfall $\left(0.34 \pm 0.05 \mathrm{~mm} \cdot \mathrm{h}^{-1}\right)$ was significantly less than measured for hours in which the radar was also detecting precipitation $\left(0.99 \pm 0.08 \mathrm{~mm} \cdot \mathrm{h}^{-1}\right)$. There were some periods where only the radar detected precipitation, but the mean number of hours that this condition occurred was an order of magnitude smaller $\left(20 \pm 8 \mathrm{~h} \cdot \mathrm{yr}^{-1}\right)$ than the mean number of hours during the test period where only the gauges were detecting rainfall $\left(197 \pm 14 \mathrm{~h} \cdot \mathrm{yr}^{-1}\right)$. The relative number of hours of radar rainfall detection, and ratio of radar-detected to gauge-detected precipitation increased after radar programming changes in 2002 and 2003 (Fig. 3).

Xie et al. (2006) found similar patterns of radar detection errors for two NEXRAD locations in New Mexico. Xie et al. (2006), however, were comparing gauge estimates to radar estimates from Stage III data, which had already gone through multisensor bias adjustment. Current methods for postprocessing bias adjustment might be inappropriate for estimating cumulative precipitation for radar locations where the majority of gauge events occur below the detection threshold set by the pdf function. This type of systematic threshold detection error might be underrepresented in the literature as most radar gauge comparisons focus on storm totals for higher intensity events or specifically ignore lower intensity events that occur during the test periods (Austin 1987; Klazura and Kelly 1995; Anagnostou and Krajewski 1998; Baeck and Smith 1998; Brandes et al. 1999; Fulton 1999; Steiner et al. 1999; Ulbrich and Lee 1999; Seo et al. 2000). Stage I, Level III radar data from the Boise location, therefore, might not be suitable for long-term water balance and natural resource modeling applications that require estimates of total annual rainfall. Because both gauges and radar were more likely to detect rainfall at the same time during higher-intensity storm events, these data could still be very useful for applications such as flood forecasting and modeling debris flow and erosion events during thunderstorm activity. Indeed, the correlation of gauge and radar precipitation events is relatively good for data obtained after November 2003 (Fig. 4C). Storm activity during these events, however, could still benefit from postprocessing bias adjustment with gauge readings as the Boise radar overestimated gauge catch for this time period.

Data processing procedures that could improve the accuracy of NEXRAD precipitation estimates must be implemented at the Stage I, Level II processing stage. Anagnostou and Krajewski (1999a) describe a detailed methodology to optimize Stage I, Level II radar data for spatial precipitation estimation. These processing steps have been shown to reduce the discrepancy between radar and gauge rainfall estimates over a given radar measurement domain (Anagnostou and Krajewski 1999b). Direct access to Level II radar data is available for research applications but is impractical for many, if not most, potential users of this technology (Crum and Kelleher 1997; Crum et al. 1998; Kruger et al. 1999; Del Greco 2003). Current systems for direct access to Stage I, Level II data require an extremely large data storage capacity for even a single day of data (Crum and Kelleher 1997; Huggins and Kingsmill 1999; James et al. 2000; Del Greco 2003). Real-time access for watershed and land management applications in the $<10000 \mathrm{~km}^{2}$ spatial range could be facilitated by development of programming code to reduce data storage requirements for users who can directly access Level II data (Kruger and Krajewski 1997). Real-time Level II data storage requirements could be reduced by immediate processing to eliminate data that do not pertain to precipitation, or are outside the specific spatial domain of interest. These reduced data sets could retain individual scan estimates of reflectivity, at all elevation angles, for the higherresolution, Level II grid array. Individual users could then apply optimization procedures of the type described by Anagnostou and Krajewski (1999a) to produce high resolution precipitation estimates specific to their watershed or field site of interest.

\section{MANAGEMENT IMPLICATIONS}

As they currently exist, Stage I, Level III precipitation data for the Boise $(\mathrm{CBX})$ radar are unsuitable for rangeland management and natural resource modeling applications, which require calculation of total annual precipitation. These data could be useful for extreme event modeling applications but are relatively difficult to access and process. Accuracy of estimation for total annual precipitation might be higher for radar locations in other climatic regimes. We suggest that programming modifications to the current precipitation processing system would facilitate bias evaluation and enhance the utility of these radar data for a large number of potential users of radar detection technology.

\section{ACKNOWLEDGMENTS}

We would like to thank the personnel at the National Weather Service, Northwest River Forecast Center in Portland, Oregon and the Hydrologic Research Laboratory in Silver Springs, Maryland for assistance in obtaining data and programming code for data processing. We would also like to thank Kathleen Healy for creating the programs used in this study for decoding and georeferencing the data.

\section{LITERATURE CITED}

Anagnostou, E. N., and W. F. Krajewski. 1998. Calibration of the WSR-88D precipitation processing subsystem. Weather and Forecasting 13:396-406.

Anagnostou, E. N., and W. F. Krajewski. 1999a. Real-time radar rainfall estimation. Part I: Algorithm formulation. Journal of Atmospheric and Oceanic Technology 16:189-197.

Anagnostou, E. N., and W. F. Krajewski. 1999b. Real-time radar rainfall estimation. Part II: case study. Journal of Atmospheric and Oceanic Technology 16:198205. 
Anagnostou, E. N., W. F. Krajewski, D.-J. Seo, and E. R. Johnson. 1998. Mean-field radar rainfall bias studies for WSR-88D. ASCE Journal of Engineering Hydrology 3:149-159.

Anagnostou, E. N., W. F. Krajewski, and J. Smith. 1999. Uncertainty quantification of mean-areal radar-rainfall estimates. Journal of Atmospheric and Oceanic Technology 16:206-215.

Austin, P. M. 1987. Relation between measured radar reflectivity and surface rainfall. Monthly Weather Review 115:1053-1070.

BaECK, M. L., AND J. A. Smith. 1998. Rainfall estimation by the WSR-88D for heavy rainfall events. Weather and Forecasting 13:416-436.

Brandes, E. A., J. Vivekanandan, and J. W. Wilson. 1999. A comparison of radar reflectivity estimates of rainfall from collocated radars. Journal of Atmospheric and Oceanic Technology 16:1264-1272.

Brandes, E. A., D. S. Zrnic, G. E. Klazura, C. F. Suprenant, and D. Sirmans. 1991. The next generation weather radar (WSR-88D) as an applied research tool. In: Proceedings of the 25th International Conference on Radar Meteorology; 2428 June 1991; Paris, France. Boston, MA, USA: American Meteorological Society. p. 47-50.

Brown, R. A., J. M. JanISH, AND V. T. Wood. 2000. Impact of WSR-88D scanning strategies on severe storm algorithms. Weather and Forecasting 15:90-102.

Carpenter, T. M., K. P. Georgakakos, and J. A. Sperfslagea. 2001. On the parametric and NEXRAD-radar sensitivities of a distributed hydrologic model suitable for operational use. Journal of Hydrology 253:169-193.

Ciach, G. J., AND W. F. KRAJeWsKI. 1999. Radar-rain gauge comparisons under observational uncertainties. Journal of Applied Meteorology 38:1519-1525.

Ciach, G. J., M. L. Morrissey, and W. F. KrajeWski. 2000. Conditional bias in radar rainfall estimation. Journal of Applied Meteorology 39:1941-1946.

Crum, T. D., and R. L. Alberty. 1993. The WSR-88D and the WSR-88D operational support facility. Bulletin of the American Meteorological Society 74:16691687.

Crum, T., and K. Kelleher. 1997. Real-time distribution of WSR-88D base data, present and future. In: Proceedings of the 28th Conference on Radar Meteorology; 7-12 September 1997; Austin, TX, USA. Boston, MA, USA: American Meteorological Society. p. 282-283.

Crum, T. D., R. E. Saffle, and J. W. Wilson. 1998. An update on the NeXRAD program and future WSR-88D support to operations. Weather and Forecasting 13:253-262.

Del Greco, S. A. 2003. A history for WSR-88D Level II data services at the National Climatic Data Center. In: Proceedings of the 31st Conference on Radar Meteorology; 6-12 August 2003; Seattle, WA, USA. Boston, MA, USA: American Meteorological Society. p. 902-906.

DI LUzIO, M., AND J. G. ARNoLD. 2004. Formulation of a hybrid calibration approach for a physically based distributed model with NEXRAD data input. Journal of Hydrology 298:136-154.

Fulton, R. A. 1998. WSR-88D Polar-to-HRAP mapping. National Weather Service, Hydrologic Research Laboratory, Technical Memorandum 9-9-01. http://www. nws.noaa.gov/oh/hrl/papers/papers.htm. Accessed 7 February 2001.

FuLton, R. A. 1999. Sensitivity of WSR-88D rainfall estimates to the rain-rate threshold and rain gauge adjustment: a flash flood case study. Weather and Forecasting 14:604-624.

Fulton, R. A., J. P. Breidenbach, D.-J. Seo, D. A. Miller, and T. O’Bannon. 1998. The WSR-88D rainfall algorithm. Weather and Forecasting 13:377-395.

Fulton, R. A., F. Ding, and D. A. Miller. 2003. Truncation errors in historical WSR88D rainfall products. In: Proceedings of the 31st Conference on Radar Meteorology; 6-12 August 2003; Seattle, WA, USA. Boston, MA, USA: American Meteorological Society. p. 270-273.

GLITTO, P., AND B. Choy. 1997. A comparison of WSR-88D storm total precipitation performance during two tropical systems following changes to the multiplicative bias and upper reflectivity threshold. Weather and Forecasting 12:459-471.

Hanson, C. L., G. L. Johnson, and A. Rango. 1999. Comparison of precipitation catch between nine measuring systems. Journal of Hydrologic Engineering 4:70-75.

Hossain, F., E. N. Anagnostou, T. Dinku, and M. Borga. 2004. Hydrological model sensitivity to parameter and radar rainfall estimation uncertainty. Hydrological Processes 18:3277-3291.
Huggins, A. W., And D. E. KIngsmiLl. 1999. Quantitative precipitation estimates from a mountain-top WSR-88D: data pre-processing considerations. In: Proceedings of the 29th International Conference on Radar Meteorology; 12-16 July 1999; Montreal, Quebec, Canada. Boston, MA, USA: American Meteorological Society. p. 709-712.

HUNTER, S. M. 1996. WSR-88D radar rainfall estimation: capabilities, limitations and potential improvements. National Weather Digest 20:26-38.

Hunter, S., B. Vieux, F. Ogden, J. Niedzialek, C. Downer, J. Addiego, and J. Daraio. 2003. A test of two distributed hydrologic models with WSR-88D radar precipitation data input in Arizona. In: Proceedings of the 31st Conference on Radar Meteorology; 6-12 August 2003; Seattle, WA, USA. Boston, MA, USA: American Meteorological Society. p. 710-713.

Istok, M. J., R. Elvander, R. Saffle, and J. Roe. 2003. neXrad product improvement-implementing new science. In: Proceedings of the 31st Conference on Radar Meteorology; 6-12 August 2003; Seattle, WA, USA. Boston, MA, USA: American Meteorological Society. p. 850-853.

James, C. N., S. R. Brodzik, H. Edmon, R. A. Houze, and S. E. Yuter. 2000. Radar data processing and visualization over complex terrain. Weather and Forecasting 15:327-338

Jordan, P. W., A. W. Seed, and P. E. Weinmann. 2003. A stochastic model of radar measurement errors in rainfall accumulations at catchment scale. Journal of Hydrometeorology 5:841-855.

KInGSMILL, D. E., AND A. W. HugGins. 1999. Quantitative precipitation estimates from a mountain-top WSR-88D: the 1997 new year's flood. In: Proceedings of the 29th International Conference on Radar Meteorology; 12-16 July 1999; Montreal, Quebec, Canada. Boston, MA, USA: American Meteorological Society. p. 713-716.

Klazura, G. E., and D. S. Kelly. 1995. A comparison of high resolution rainfall accumulation estimates from the WSR-88D precipitation algorithm with rain gage data. In: Proceedings of the 27th Conference on Radar Meteorology; 913 October 1995; Vail, CO, USA. Boston, MA, USA: American Meteorological Society. p. 31-34.

Koren, V. I., B. D. Finnerty, J. C. Schaake, M. B. Smith, D.-J. Seo, and Q. Y. Duan. 1999. Scale dependencies of hydrologic models to spatial variability of precipitation. Journal of Hydrology 217:285-302.

Kruger, A., and W. F. KrajeWski. 1997. Efficient storage of weather radar data. Software Practice and Experience 27:623-635.

Kruger, A., W. F. Krajewski, D.-J. Seo, and J. P. Breidenbach. 1999. Development of a large radar database for hydrometeorological studies. In: Proceedings of the 29th International Conference on Radar Meteorology; 12-16 July 1999; Montreal, Quebec, Canada. Boston, MA, USA: American Meteorological Society. p. 945-948.

Maddox, R. A., J. Zhang, J. J. Gourley, and K. W. Howard. 2002. Weather radar coverage over the contiguous United States. Weather and Forecasting 17: 927-934.

Morin, E., W. F. Krajewski, D. C. Goodrich, X. Gao, and S. Sorooshian. 2003. Estimating rainfall intensities from weather radar data: the scale dependency problem. Journal of Hydrometeorology 4:782-797.

Neary, V. S., E. HabiB, and M. Fleming. 2004. Hydrologic modeling with NEXRAD precipitation in middle Tennessee. Journal of Hydrologic Engineering 9:339349 .

Nelson, J. A., J. A. Jackman, M. I. Biggerstaff, and D. Austin. 1996. Agricultural applications of the hourly digital precipitation array (HDP) from the WSR-88D (NEXRAD) doppler radars. In: Proceedings of the 22nd Conference on Agricultural and Forest Meteorology; 28 January-2 February 1996; Atlanta, GA, USA. Boston, MA, USA: American Meteorological Society. $p$. 339-340.

Reed, S. M., and D. R. Maidment. 1999. Coordinate transformations for using NEXRAD data in GIS-based hydrologic modeling. Journal of Hydrologic Engineering 4:174-182.

Seed, A. W., J. Nicol, G. L. Austin, C. D. Stow, and S. G. Bradley. 1996. The impact of radar and raingauge sampling errors when calibrating a weather radar. Meteorological Applications 3:43-52.

SEO, D.-J. 1998. Real-time estimation of rainfall fields using radar rainfall and rain gage data. Journal of Hydrology 208:37-52. 
Seo, D.-J., J. Briedenbach, R. Fulton, D. Miller, and T. O’Bannon. 2000. Real-time adjustment of range-dependent biases in WSR-88D rainfall estimates due to nonuniform vertical profile of reflectivity. Journal of Hydrometeorology 1:222-240.

Seo, D.-J., J. P. Breidenbach, and E. R. Johnson. 1999. Real-time estimation of mean field bias in radar rainfall data. Journal of Hydrology 223:131-147.

Sharif, H. O., F. L. Ogden, W. F. Krajewski, and M. Xue. 2004. Statistical analysis of radar rainfall error propagation. Journal of Hydrometeorology 5:199-212.

Smith, J. A., D.-J. Seo, M. L. BAeck, And M. D. Hudlow. 1996. An intercomparison study of NEXRAD precipitation estimates. Water Resources Research 32: 2035-2045.

Snow, J. T., AND R. B. Scott. 2003. Strategic directions for WSR-88D Doppler weather surveillance radar in the period 2007-2025. In: Proceedings of the 31st Conference on Radar Meteorology; 6-12 August 2003; Seattle, WA, USA. Boston, MA, USA: American Meteorological Society. p. 948-951.

Steiner, M., J. A. Smith, S. J. Burges, C. V. Alonso, and R. W. Darden. 1999. Effect of bias adjustment and rain gauge data quality control on radar rainfall estimation. Water Resources Research 35:2487-2503.

Ulbrich, C. W., AND L. G. LeE. 1999. Rainfall measurement error by WSR-88D radars due to variations in Z-R law parameters and the radar constant. Journal of Atmospheric and Oceanic Technology 16:1017-1024.

Warner, T. T., E. A. Brandes, J. Z. Sun, D. N. Yates, and C. K. Mueller. 2000. Prediction of a flash flood in complex terrain. Part I: A comparison of rainfall estimates from radar, and very short range rainfall simulations from a dynamic model and an automated algorithmic system. Journal of Applied Meteorology 39:797-814.

Westrick, K. J., C. F. Mass, and B. A. Colle. 1999. The limitations of the WSR-88D radar network for quantitative precipitation measurement over the coastal western United States. Bulletin of the American Meteorological Society 80: 2289-2298.
Whiton, R. C., P. L. Smith, S. G. Bigler, K. E. Wilk, and A. C. Harbuck. 1998a. History of operational use of weather radar by US weather services. Part I: the preNEXRAD era. Weather and Forecasting 13:219-243.

Whiton, R. C., P. L. Smith, S. G. Bigler, K. E. Wilk, and A. C. Harbuck. 1998b. History of operational use of weather radar by US weather services. Part II: development of operational Doppler weather radars. Weather and Forecasting 13:244-252.

Winchell, M., H. V. Gupta, And S. Sorooshian. 1998. On the simulation of infiltrationand saturation-excess runoff using radar-based rainfall estimates: effects of algorithm uncertainty and pixel aggregation. Water Resources Research 34:2655-2670.

Witt, A., M. D. Ellts, G. J. Stumpf, J. T. Johnson, E. D. Mitchell, and K. W. Thomas. 1998a. An enhanced hail detection algorithm for the WSR-88D. Weather and Forecasting 13:286-303.

Witt, A., M. D. Ellts, G. J. Stumpf, E. D. Mitchell, J. T. Johnson, and K. W. Thomas. 1998b. Evaluating the performance of WSR-88D severe storm algorithms. Weather and Forecasting 13:513-518.

Xie, H., X. Zhou, J. M. H. Hendrickx, E. R. Vivoni, H. Guan, Y. Q. Tian, and E. E. Small. 2006. Evaluation of NEXRAD Stage III precipitation data over a semi-arid region. Journal of the American Water Resources Association 42:237-256.

Young, C. B., A. A. Bradley, W. F. Krajewski, A. Kruger, and M. L. Morrissey. 2000. Evaluating NEXRAD multisensor precipitation estimates for operational hydrologic forecasting. Journal of Hydrometeorology 1:241-254.

Young, C. B., B. R. Nelson, A. A. Bradley, J. A. Smith, C. D. Peters-Lidard, A. Kruger, AND M. L. BAECK. 1999. An evaluation of NEXRAD precipitation estimates in complex terrain. Journal of Geophysical Research-Atmospheres 104:19691-19703.

Zhang, Z., V. Koren, M. Smith, S. Reed, and D. Wang. 2004. Use of next generation weather radar data and basin disaggregation to improve continuous hydrograph simulations. Journal of Hydrologic Engineering 9:103-115. 